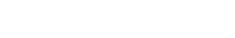

\title{
Influence of non-genetic factors on body weight traits of goats reared in hot humid climate
}

\author{
R. THIRUPATHY VENKATACHALAPATHY, P.M. ROJAN AND G.N. PREMKRISHNAN
}

\begin{abstract}
Growth is of great economic importance and requires particular attention for increasing total productivity in goat. The birth weight and early growth rate of animals are determined not only by genetic potential and also by maternal and environmental factors. Hence, an attempt has been made to know the effects of various non-genetic factors on the body weight at birth and different stages of growth. Data were collected from 180 goats belongs three genetic groups viz., Mablabari, Attappaddy and crossbred Malabari maintained at Goat and Sheep farm, Kerala Veterinary and Animal Sciences University, Mannuthy for the period from 2010 to 2013. The traits recorded were birth weight (BW), body weight at three (BW3), six (BW6) and nine months (BW9) of age. Birth weight (BW), body weight at three (BW3), six (BW6) and nine months (BW9) were analyzed to find out the effects non-genetic factors viz., breed, sex, season and type of birth using least square fixed model analysis of variance as described by Harvey (1990) for non-orthogonal data. Crossbred had significantly higher body weights at birth, three, six and nine months of age than Malabari and Attappady goat breed. However, the two native breeds of Kerala (Malabari and Attappady) did not differ significantly with respect to body weight at different stages of age. Season had significant influence on birth weight. Kids born as single had significant growth rate compared to twins and triplets upto nine months of age.
\end{abstract}

KEY WORDS : Non-genetic factors, Malabari goat, Attappdy goat

How TO CITE THIS PAPER : Venkatachalapathy, R. Thirupathy, Rojan, P.M. and Premkrishnan, G.N. (2015). Influence of non-genetic factors on body weight traits of goats reared in hot humid climate. Res. J. Animal Hus. \& Dairy Sci., 6(1) : 37-40.

Address for correspondence :

R. Thirupathy Venkatachalapathy, Goat and Sheep Farm, Mannuthy, THRISSUR (KERALA) INDIA

Email : pathy51@rediffmail.com

Associated Authors' :

P.M. Rojan and G.N. Premkrishnan, Centre for Advanced Studies in Animal Genetics and Breeding, Kerala Veterinary and Animal Sciences University, Mannuthy, THRISSUR (KERALA) INDIA 